2. To: (Receiving Organization)

FIELD ANALYTICAL SERVICES

5. Proj./Prog./Dept./Div.:

THRS ENG/CHAR SUPPORT

8. Originator Remarks:

N/A
3. From: (Originating organization) TWRS/CHARACTERIZATION SUPPORT

6. Cog. Engr.:

B. C. CARPENTER

4. Related EDT MO.:

$N / A$

7. Purchase Order Mo.:

N/A

9. Equip./Component No.:

$N / A$

10. System/Bldg./Facility:

2750E/200E

11. Receiver Remarks:

12. Major Assm. Owg. No.: $N / A$

13. Permit/Permit Application Ho.: $N / A$

14. Requi red Response Date: $11 / 30 / 94$

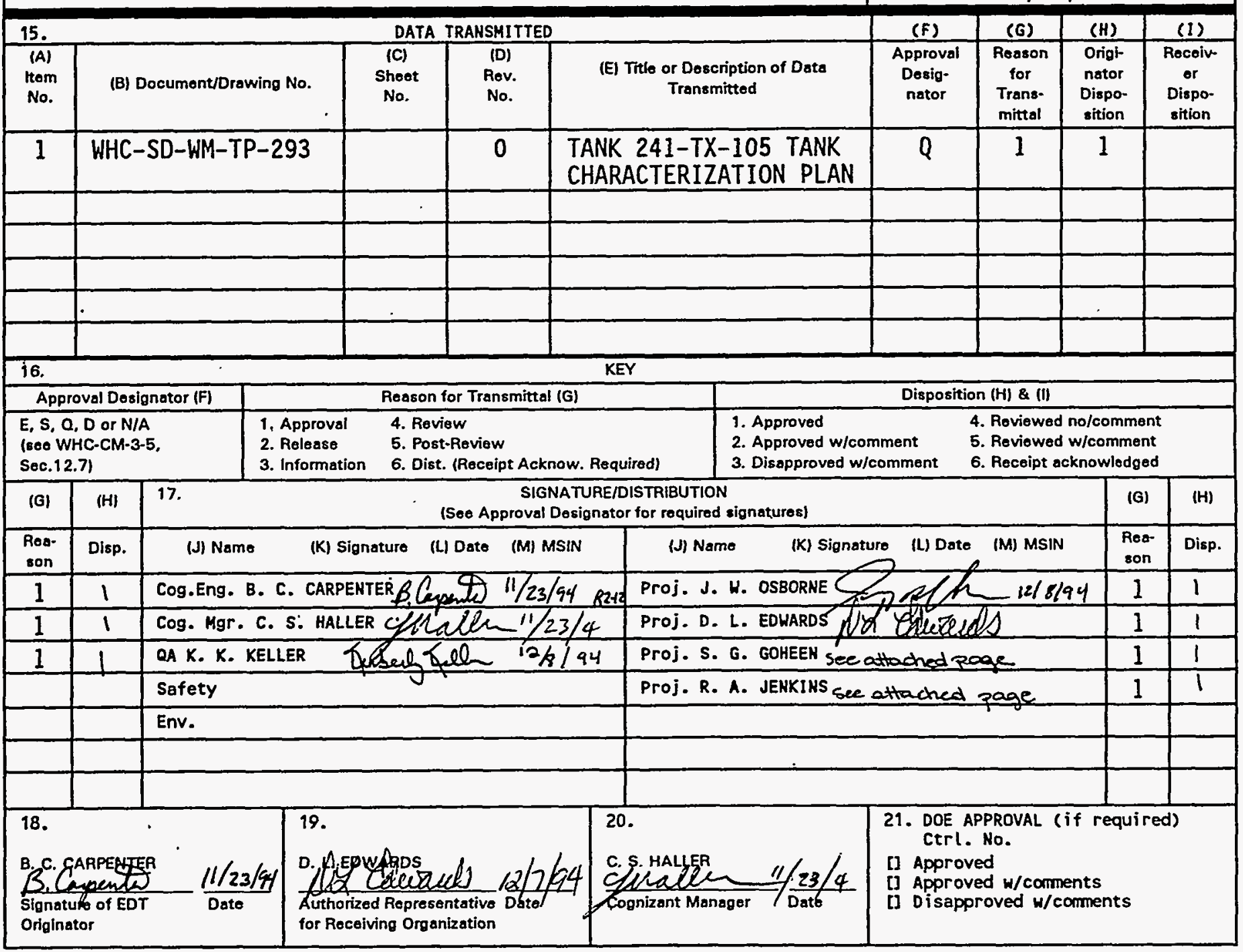

BD-7400-172-2 (04/94) GEF097 


\section{DISCLAIMER}

Portions of this document may be illegible in electronic image products. Images are produced from the best available original document. 


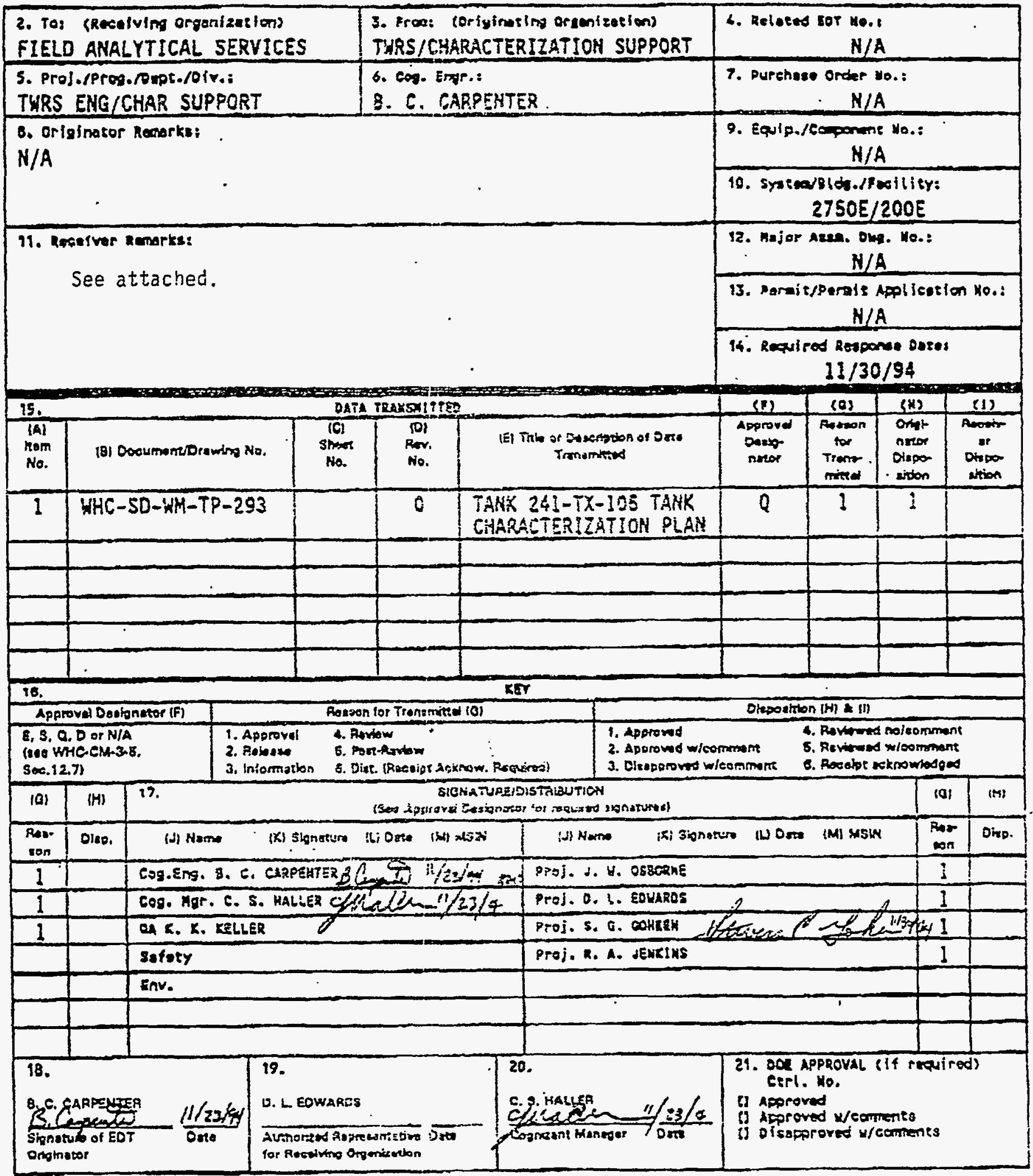




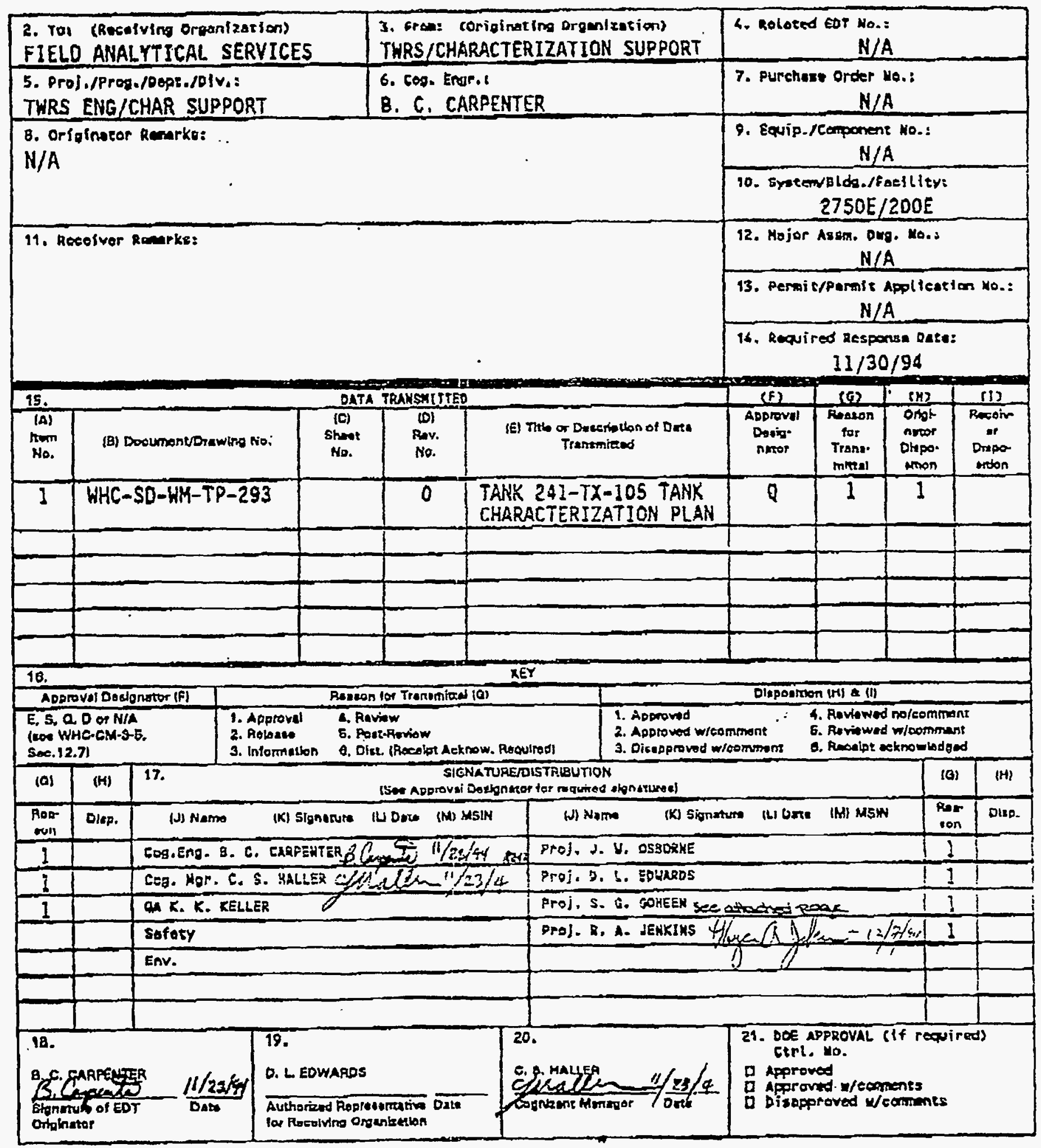

BD-7400-172:2 (04/96) GEFOS? 


\section{RELEASE AUTHORIZATION}

Document Number: $\quad$ WHC-SD-WM-TP-293, REV.0

Document Title: TANK 241-TX-105 TANK CHARACTERIZATION PLAN

Release Date: December 8, 1994

This document was reviewed following the
procedures described in WHC-CM-3-4 and is:

APPROVED FOR PUBLIC RELEASE

WHC Information Release Administration Specialist:

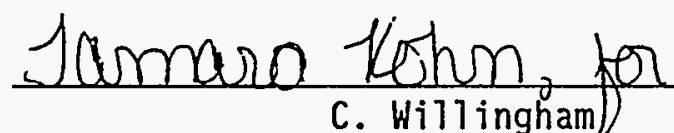

December 8, 1994

TRADEMARK DISCLAIMER. Reference herein to any specific comercial product, process, or service by trade name, trademark, manufacturer, or otherwise, does not necessarily constitute or imply its endorsement, recormendation, or favoring by the United States Government or any agency thereof or. its contractors or subcontractors.

This report has been reproduced from the best available copy. Available in paper copy and microfiche. Printed in the United States of America. Available to the U.S. Department of Energy and its contractors from:

U.S. Department of Energy

office of Scientific and Technical Information (OSTI)

- P.0. Box 62

Oak Ridge, TN 37831

Telephone: (615) 576-8401

Available to the public from:

U.S. Department of Commerce

National Technical Information Service (NTIS)

5285 Port Royal Road

Springfield, VA 22161

Telephone: (703) $487-4650$ 


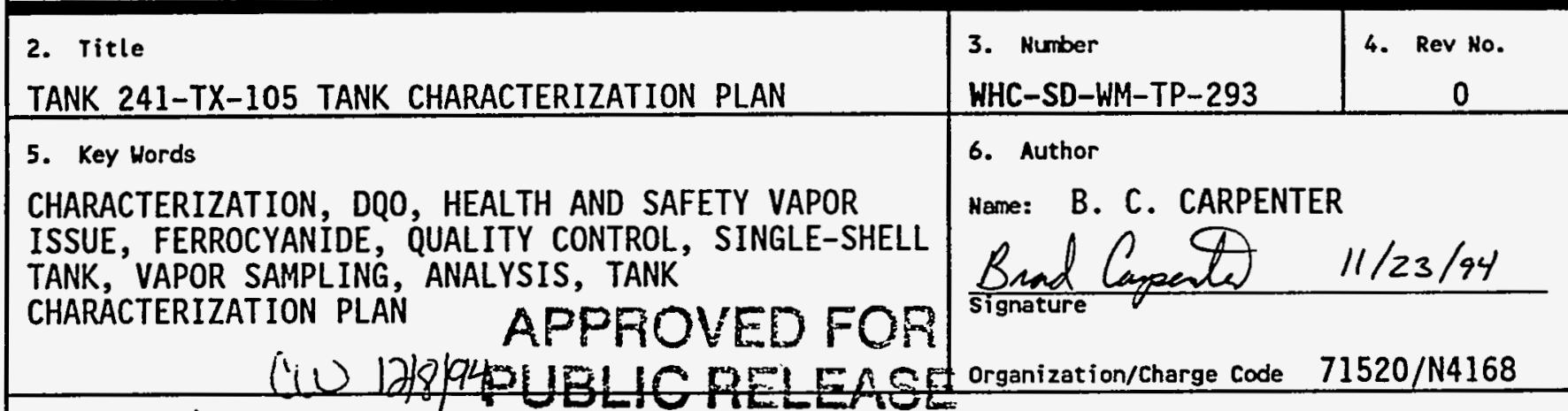

\section{Abstract}

This document is a plan which serves as the contractual agreement between the Characterization Program, Sampling Operations, WHC 222-S Laboratory, Oak Ridge National Laboratory, and PNL tank vapor program. The scope of this plan is to provide guidance for the sampling and analysis of vapor samples from tank 241-TX-105. 
WHC-SD-WM-TP-293

Revision 0

\title{
Tank 241-TX-105 Tank Characterization Plan
}

\author{
Prepared for the U.S. Department of Energy \\ Office of Environmental Restoration \\ and Waste Management
}

\section{DISCLAIMER}

This report was prepared as an account of work sponsored by an agency of the United States Government. Neither the United States Government nor any agency thereof, nor any of their employees, makes any warranty, express or implied, or assumes any legal liability or responsibility for the accuracy, completeness, or usefulness of any information, apparatus, product, or process disclosed, or represents that its use would not infringe privately owned rights. Reference herein to any specific commercial product, process, or service by trade name, trademark, manufacturer, or otherwise does not necessarily constitute or imply its endorsement, recommendation, or favoring by the United States Government or any agency thereof. The views and opinions of authors expressed herein do not necessarily state or reflect those of the United States Government or any agency thereof.

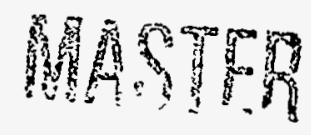




\section{TABLE OF CONTENTS}

1.0 SPECIFIC TANK CHARACTERIZATION OBJECTIVES ......... 1

1.1 Data Quality Objectives Applicable to Tank TX-105 . . . . . . I

2.0 RELEVANT SAFETY INFORMATION ............... 2

2.1 Tank Status . . . . . . . . . . . . . . . . . . 2

2.2 Tank Monitoring Activities ............ 2

3.0 SUMMARY OF HISTORICAL INFORMATION FOR TANK TX-105 ....... 2

3.1 Configuration ....................... . . 2

3.2 Process History ................... 2

3.3 Historical Sampling Events ............. 3

3.4 Expected Tank Contents ............... 4

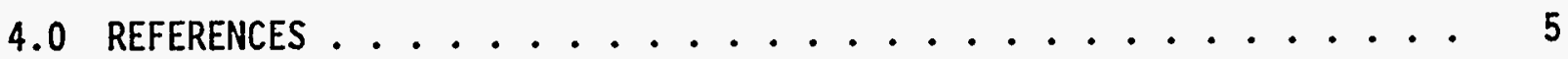

APPENDICES: TANK 241-TX-105 SAMPLING AND ANALYSIS PLAN

SAMPLE EVENT A: VAPOR SAMPLING IN FISCAL YEAR $1995 \ldots \ldots \ldots$

LIST OF TABLES

Table 1: Tank TX-105 Fill History . . . . . . . . . . . 3

Table 2. Tank TX-105 Analysis Results. ........... 4

\section{LIST OF ACRONYMS}

CW cladding waste

DQO data quality objective

DST double-shel 7 tank

EB evaporator bottoms

NCPLX noncomplexed waste

OWW organic solvent wash waste from the PUREX plant

ppmv parts per million by volume

PUREX Plutonium-Uranium Extraction plant

RCRA Resource Conservation and Recovery Act

REDOX Reduction-0xidation process

RIX REDOX ion exchange waste from $B$ plant

SST single-shell tank

TOC total organic carbon

TRAC Track Radioactive Components

TX-105 Tank 241-TX-105

TWRS

WHC

WHC Tank Waste Remediation System

Westinghouse Hanford Company 


\subsection{SPECIFIC TANK CHARACTERIZATION OBJECTIVES}

This Tank Characterization Plan will identify characterization objectives for tank TX-105 pertaining to sample collection, sample preparation and analysis, and laboratory analytical evaluation and reporting requirements in accordance with the Tank Waste Remediation System Tank Waste Analysis Plan (Haller 1994) and the applicable Data Quality Objectives identified in the following section. In addition, the current status (Section 2) and contents estimate (Section 3 ) of the tank is given.

\subsection{Data Quality Objectives Applicable to Tank TX-105}

The sampling and analytical needs associated with the 51 Hanford Site underground storage tanks classified on one or more of the four Watch Lists (ferrocyanide, organic, flammable gas, and high heat), and the safety screening of all 177 tanks have been identified through the. Data Quaility Objective (DQO) process. DQO's identify information needed by a program group in the Tank Waste Remediation System (TWRS) concerned with safety issues, regulatory requirements, or the transporting and processing of tank waste.

The Tank Safety Screening Data Quality Objective (Redus and Babad 1994) describes the sampling and analytical requirements that are used to screen waste tanks for unidentified safety issues. To meet the sampling requirements of this DQO effort, a vertical profile of the waste shall be obtained from at least two widely-spaced risers. This vertical profile may be realized using core, auger, or grab samples. The safety screening analyses shall be applied to all core samples, DST RCRA samples, and all auger samples, except auger samples taken exclusively to assess the flammable gas tank crust burn issue.

Both Watch List and non-Watch List tanks will be sampled and evaluated to classify the waste tanks into one of three categories: SAFE, CONDITIONALLY SAFE, or UNSAFE following safety parameters related to the four watch-List and other safety issues. The Watch List DQO's identify the requirements used to determine which classifjcation to place a tank, based on analyses that indicate if certain measures are above or below established thresholds. A tank can be removed from a Watch List if it is classified as SAFE. As indicated from the present status of the tank (Section 2.0), the Watch List DQO applicable to tank TX-105 is: Data Quality Objective to Support Resolution of the Organic Fuel Rich Tank Safety Issue (Babad et al., 1994).

DQO's concerned with fugitive vapor emissions from tank TX-105 are: Data Quality Objectives for Generic In-Tank Health and Safety Vapor Issue Resolution (Osborne et a7. 1994); and Rotary Sampling Core Vapor Sampling Data Quality Objective (Price 1994). Characterization of the tank headspace is needed to: 1) identify those tanks which can safely be sampled with intrusive equipment without risk of gas ignition; 2) identify and estimate concentrations of toxicologically significant compounds present in the tank headspace to establish worker safety precautions; and 3 ) support the startup and operation of the portable exhauster used during rotary mode core sampling. 


\subsection{RELEVANT SAFETY INFORMATION}

The organic safety issue arises due to wastes added to SSTs containing quantities of complexants used in waste management operations, as well as degradation products of these complexants and solvents used in fuel reprocessing and metal recovery operations. These waste tanks al so contain a presumed stoichiometric excess of sodium nitrite/nitrate oxidizers that are sufficient to exothermally oxidize organic compounds.

Resolution of tank vapor safety issues involve the identification of potential flammable and fugitive vapor emissions from tanks which could become worker health and safety hazards.

\subsection{Tank Status}

Single-shell tank TX-105 is classified as an Organic Watch List tank. The tank, categorized as an assumed leaker in 1977, was interim stabilized in 1983. To prevent further waste addition, intrusion prevention was completed in 1984. In 1984 the tank was categorized as stable.

This tank is estimated to contain $2,310,000 \mathrm{~L}(609,000$ gallons) of non-complexed waste (NCPLX) which is equivalent to $550 \mathrm{~cm}$ (217 inches) of waste as measured from the baseline of the tank. The waste is comprised of $2,310,000 \mathrm{~L}(609,000$ gallons) of saltcake containing $75,700 \mathrm{~L}(20,000$ gallons) of drainable interstitial liquid (De Lorenzo 1994). The temperature of the waste in tank TX-105 was measured at $36^{\circ} \mathrm{C}$ in June of 1994 (Hanton 1994).

Recent readings (October, 1994) obtained from Tank Farm Surveillance and the Surveillance Analysis Computer System database indicate a waste depth of $544 \mathrm{~cm}$ (214 inches) below riser 12 . From this, the total waste volume is calculated at 2,150,000 liters.

\subsection{Tank Monitoring Activities}

Waste level measurements are taken on a quarterly basis through riser 12 using a manual tape. Internal tank temperature is manually recorded from a thermocouple tree in riser 4 . Six active dry wells monitor radiation in the surrounding soil (Hanton 1994).

\subsection{SUMMARY OF HISTORICAL INFORMATION FOR TANK TX-105}

Included in this section are a physical description of tank TX-105, its process history, and recorded sampling events.

\subsection{Configuration}

Tank TX-105 is one of 18 single-shell tanks in the 200 West area TX Farm constructed during 1947-48. It is 23 meters (75 ft.) in diameter with a concave base and has a 2.87 million liter (758,000 gal.) tank capacity.

\subsection{Process History}

Tank TX-105, beginning service in the third quarter of 1952, was filled to capacity with $T$ Plant metal waste. After sluicing the metal waste, the tank received REDOX waste. In the early 70's tank TX-105 was used in 
evaporator 242-T campaigns and received a large volume of evaporator bottoms. In 1977 waste additions to tank TX-105 were halted after the tank integrity was suspected. Table 1 summarizes the fill history of tank TX-105 from 1952 to the present (Anderson 1990).

Table 1: Tank TX-105 Fill History.

\begin{tabular}{|c|c|c|}
\hline 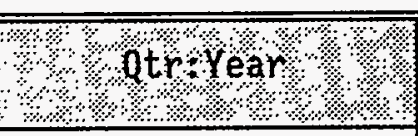 & $4 \%$ Waste type and Descrpption & Total funal vol \\
\hline $2: 1952-4: 1956$ & $\begin{array}{l}\text { Addition and transfer of Metal } \\
\text { waste to and from TX-106, TX-115 } \\
\text { and U plant }\end{array}$ & $18.9(5)$ \\
\hline $1: 1957-1: 1971$ & $\begin{array}{l}\text { Addition and transfer of REDOX } \\
\text { waste to and from SX-102, TX-107, } \\
\text { C-105, TX-101, TX-102, TX-106 and } \\
\text { BX-106 }\end{array}$ & $420 \quad(111)$ \\
\hline $2: 1971$ & $\begin{array}{l}\text { Waste categorized of EB, CW, OWW } \\
\text { and RIX }\end{array}$ & $666 \quad(176)$ \\
\hline $3: 1971-2: 1976$ & Recejved $242-T$ EB waste & $2,680(708)$ \\
\hline $3: 1976-4: 1977$ & Evaporator Feed waste & $2,310(609)$ \\
\hline $1: 1978$ & Questionable Integrity & $2,310(609)$ \\
\hline $3: 1984$ & $\begin{array}{l}\text { Primary stabilized and partially } \\
\text { interim isolated }\end{array}$ & $2,310(609)$ \\
\hline $2: 1994$ & Waste categorized as NCPLX & $2,310(609)$ \\
\hline
\end{tabular}

\subsection{Historical Sampling Events}

Three historical sample analytical reports were found in the TWRS Tank Characterization Resource Center. These are summarized in Table 2. The 1974 sample was reported as having an initial appearance of being comprised of $85 \%$ solids. However, a cooling curve test between $90^{\circ} \mathrm{C}$ and $10^{\circ} \mathrm{C}$ indicated solids forming at $60^{\circ} \mathrm{C}$ with a maximum of $40 \%$ solids at the minimum temperature. The 1976 supernatant sample was reported at a high $\mathrm{pH}$ and high dissolved aluminum concentration. The most recent sample (1981) was taken in preparation to salt well pumping and had a high concentration of organic carbon.

No known tank vapor space samples have been taken to date. However, the Industrial Hygiene and Safety Program has taken ten source sweeps of tank TX-105 vent headers spanning from September 1993 to May 1994 looking for hazardous levels (to workers) of ammonia and organics. Ammonia was not detected and organics were measured at levels ranging from 1-10 ppmv. 
Table 2. Tank TX-105 Analysis Results.

\begin{tabular}{|c|c|c|c|}
\hline \multicolumn{2}{|c|}{ Date of sample / January $/ 974$ \% } & \% August $1976 \%$ & 1. January agei: \\
\hline \multicolumn{4}{|c|}{ 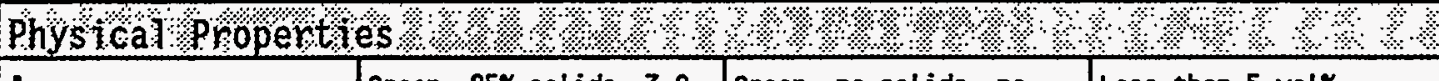 } \\
\hline Appearance & $\begin{array}{l}\text { Green, } 85 \% \text { solids, } 3.0 \\
\text { RAD/hr direct. }\end{array}$ & $\begin{array}{l}\text { Green, no solids, no } \\
\text { organic layer, } 2.7 \\
\text { RAD/hr direct. }\end{array}$ & $\begin{array}{l}\text { Less than } 5 \text { volx } \\
\text { solids. }\end{array}$ \\
\hline Density $(\mathrm{g} / \mathrm{ml})$ & NR & 1.403 & 1.356 \\
\hline $\mathrm{pH}$ & $>11.8$ & 13.2 & NR \\
\hline Thermal anal. & NR & No exotherm & NR \\
\hline $\begin{array}{l}\text { Cooling curve } \\
\text { summary }\end{array}$ & $\begin{array}{l}40 \% \text { solids at } \\
10^{\circ} \mathrm{C}\end{array}$ & No solids at $5^{\circ} \mathrm{C}$ & $\begin{array}{l}\text { Very thick, many } \\
\text { crystals at } 10^{\circ} \mathrm{C}\end{array}$ \\
\hline \multicolumn{4}{|c|}{ Chemical Constituents, $\mu \mathrm{g} / \mathrm{g}$ unless noted otherwise,} \\
\hline$A 7^{3+}$ & NR & 19,400 & 9,960 \\
\hline $\mathrm{Na}^{+}$ & $13.82 \mathrm{M}$ & $(0.141 \mathrm{M}) \quad 2,310$ & NR \\
\hline $\mathrm{CO}_{3}^{2-}$ & NR & 43,000 & 48,200 \\
\hline $\mathrm{PO}_{4}^{2-}$ & $0.139 \mathrm{M}$ & $(<0.01 \underline{M})<700$ & $(0.09 \mathrm{M}) \quad 6,300$ \\
\hline $\mathrm{Cl}^{-}$ & NR & 5,510 & NR \\
\hline $\mathrm{F}^{-}$ & NR & 13 & NR \\
\hline $\mathrm{OH}^{-}$ & $2.96 \mathrm{M}$ & $(2.16 \mathrm{M}) 26,200$ & $(1.27 \mathrm{M}) \quad 15,900$ \\
\hline TOC & NR & NR & 105,000 \\
\hline HEDTA & NR & NR & $<1,500$ \\
\hline EDTA & NR & NR & $<1,500$ \\
\hline Water (wt \%) & 35.33 & NR & 58.6 \\
\hline \multicolumn{3}{|c|}{ Radionuclide constituents 2 - } & $3 \quad 3 \quad 3$ \\
\hline${ }^{137} \mathrm{Cs}$ & $1,500 \mu \mathrm{Ci} / \mathrm{mL}$ & $339 \mu \mathrm{Ci} / \mathrm{g}$ & NR \\
\hline${ }^{134} \mathrm{Cs}$ & $13.0 \mu \mathrm{Cj} / \mathrm{mL}$ & $0.98 \mu \mathrm{Cj} / \mathrm{g}$ & NR \\
\hline${ }^{125} \mathrm{Sb}$ & $3.28 \mu \mathrm{Ci} / \mathrm{mL}$ & NR & NR \\
\hline${ }^{89,90} \mathrm{Sr}$ & NR & $1.47 \mu \mathrm{Ci} / \mathrm{g}$ & NR \\
\hline $\mathrm{Pu}$ & NR & $0.074 \mu \mathrm{g} / \mathrm{g}$ & NR \\
\hline
\end{tabular}

NR = Not reported

\subsection{Expected Tank Contents}

Tank TX-105 is expected to hold one primary layer of saltcake waste which retains drainable interstitial liquid and a high organic residue. The waste is believed to contain up to $3.7 \%$ organic carbon on a dry weight basis. However, the organic composition was derived from data developed by TRAC computer code (Hanlon 1994). Other vapors of concern expected to be present in the vapor space are methane, nitric oxide, and nitrous oxide. 
WHC-SD-WM-TP-293, REV 0

\subsection{REFERENCES}

Anderson, J. D., 1990, A History of the 200 Area Tank Farms, WHC-MR-0132, Westinghouse Hanford Company, Richland, Washington.

Babad, H., S. M. Blacker, K. S. Redus, 1994, Data Quality Objective to Support Resolution of the Organic Fue7 Rich Tank Safety Issue, WHC-SD-WM-DQ0-006, Rev. 0, Westinghouse Hanford Company, Richland, Washington.

De Lorenzo, D., 1994, Tank Characterization Reference Guide, WHC-SD-WM-TI-648, Rev. 0, Westinghouse Hanford Company, Richland, Washington.

Haller, C. S., 1994, Fiscal Year 1995 Tank Waste Remediation System Tank Waste Analysis Plan, WHC-SD-WM-PLN-091, Rev. 0, Westinghouse Hanford Company, Richland, Washington.

Hanlon, B. M., 1994, Tank Farm Surveillance and Waste Status Summary Report for July 1994, WHC-EP-0182-75, Westinghouse Hanford Company, Richland, Washington.

Jansky, M. T., 1981, Viscosity and Characterization of TX Samples, (interna] letter 65453-81-029 to J. W. Bailey, February 3) Rockwell International, Richland, Washington.

Jansky, M. T., 1981, Nitrate and Nitrite Content of TX Salt Well Samples, (internal letter 65453-81-038 to H. J. Eding, February 10) Rockwe11 Internationa1, Richland, Washington.

Price D. N., 1994, Rotary Core Vapor Sampling Data Quality Objective, WHC-SDWM-SP-003, Rev. 0, Westinghouse Hanford Company, Richland, Washington.

Osborne, J. H., J. L. Huckaby, E. R. Hewitt, C. M. Anderson, D. D. Mahlum, B. A. Pulsipher, J. Y. Young, 1994, Data Quality Objectives for Generic InTank Hea7th and Safety Vapor Issue Resolution, WHC-SD-WM-DQ0-002, Rev. 0, Westinghouse Hanford Company, Richland, Washington.

Redus, K. S., and H. Babad, 1994, Tank Safety Screening Data Quality Objective WHC-SD-WM-SP-004, Westinghouse Hanford Company, Richland, Washington.

Sant, H. H., 1974, Special Sampling of 241-TX Farm Tanks. Sample: T-805, 105-TX, (internal memo to R. L. Walser, January 21), Atlantic Richfield Hanford Company, Richland, Washington.

Supervisor, Analytical Services, 1977, Analyses of Tank Farm Sample. Sample No: T6311, Tank: 105-TX, Received: 08/19/76, (non-adḍressed internal memo data sheet, February 22), Atlantic Richfield Hanford Company, Richland, Washington. 
WHC-SD-WM-TP-293, REV 0

\title{
APPENDICES
}

\author{
TANK 241-TX-105 \\ SAMPLING AND ANALYSIS PLAN
}


WHC-SD-WH-TP-293, APPENDIX A, REV 0

SAMPLE EVENT A

\section{VAPOR SAMPLING \\ IN FISCAL YEAR 1995}

A. 0 
WHC-SD-WM-TP-293, APPENDIX A, REV 0

SAMPLE EVENT A: VAPOR SAMPLING IN FISCAL YEAR 1995

TABLE OF CONTENTS

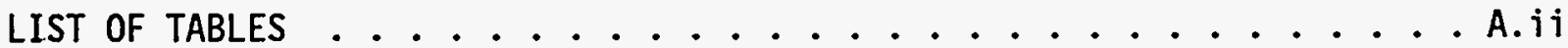

LIST OF FIGURES ............................ . . . .

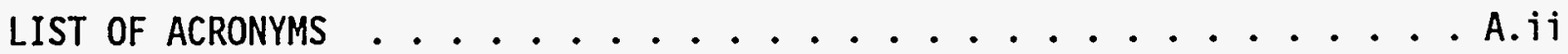

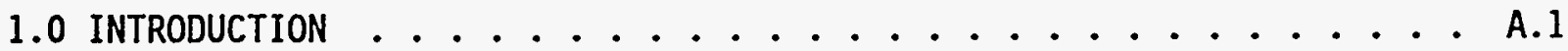

2.0 SCHEDULED SAMPLING EVENT ............... A.1

2.1 Preparation of Sample Media Containers . . . . . . . . A.1

2.2 Flammability of Vapor Space Gases . . . . . . . . . A.1

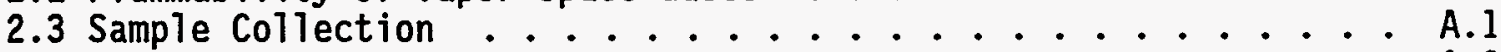

2.4 Radiation Screening and Sample Transport ............... A.

2.5 Tank-Specific Analytical Procedures .......... A.4

3.0 QUALITY ASSURANCE/QUALITY CONTROL . . . . . . . . . . A.7

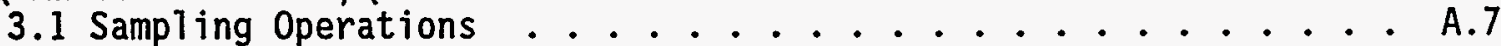

3.2 Laboratory Operations . . . . . . . . . . . A.8

4.0 ORGANIZATION . . . . . . . . . . . . . . . . . . . . .

5.0 EXCEPTIONS, CLARIFICATIONS, AND ASSUMPTIONS . . . . . . A.9

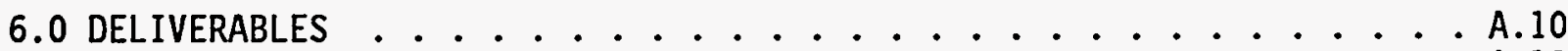

6.1 Format I Reporting ................... . . . . . .

6.2 Format II Reporting . . . . . . . . . A.10

6.3 Format VI Reporting .................... . . .

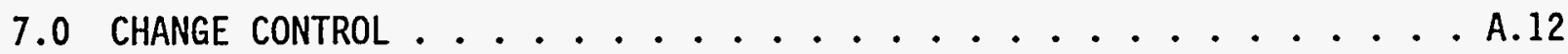

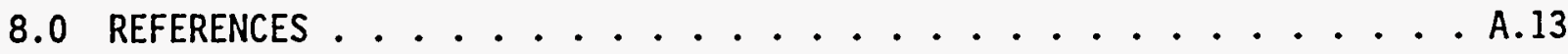




\section{LIST OF TABLES}

Table A.1. General Sampling Information . . . . . . . . . . . A.2 Table A.2. List of Samples and Activities. . . . . . . . . . . . A.3

Table A.3. Limits For Acceptable Radionuclide Activity Levels. . . . . A.4

Table A.4. TX-105 Sample Chemical, Physical, and Radiological Analytical Requirements .................. A.6

Table A.5. Tank TX-105 Project Key Personnel List. . . . . . . . . A.9

\section{LIST. OF FIGURES}

Figure A.1. Test Plan Outline and Flowchart for Tank Vapor Space

Characterization. . . ................ A.5

\section{LIST OF ACRONYMS}

CERCLA Comprehensive Environmental Response, Compensation, and Liability Act of 1980

CGM combustible gas meter

DOT Department of Transportation

DQO data quality objective

EPA Environmental Protection Agency

ESH\&QA Environmental Safety, Health, and Quarity Assurance

FAS

Field Analytical Services

GC/MS gas chromatography/mass spectrometry

HEPA high efficiency particulate air

IC ion chromatography

IDLH immediately dangerous to life and health

LFL lower flammability limit

OGIST Oregon Graduate Institute of Science and Technology

ORNL Oak Ridge National Laboratory

PNL - Pacific Northwest Laboratory

ppbv parts per billion by volume.

ppmv parts per million by volume

RCRA Resource Conservation and Recovery Act

SML Sampling and Mobile Laboratories

SUMMA ${ }^{\circledR} \quad$ registered trademark for passivated stainless steel canister

TCP Tank Characterization PIan

TNMHC Total Non-Methane Hydrocarbons

T0-12 EPA task order protocol 12

T0-14 EPA task order protocol 14

TOC total organic carbon

TWRS Tank Waste Remediation System

TX-105 Tank 241-TX-105

VSS vapor sampling system

WHC Westinghouse Hanford Company 


\section{WHC-SD-WH-TP-293, APPENDIX A, REV 0 \\ TANK 241-TX-105 VAPOR SPACE SAMPLING AND ANALYSIS PLAN}

\subsection{INTRODUCTION}

Vapor samples are used to identify potential flammable and fugitive vapor emissions from the tanks which could become worker health and safety issues. Sampling of the vapor space can identify: 1) volatile compounds above the surface of the waste; and 2) the amount of gases generated by chemical or radiolytic reactions within the waste.

\subsection{SCHEDULED SAMPLING EVENT}

The following information provides the methodology and procedures to be used in the preparation, retrieval, transport, analysis, and reporting of results for vapor space samples retrieved from tank TX-105. The requirements for sample event $A$, contained within this appendix of the TCP, are within the scope of work specified in the appropriate laboratory financial plans. Any decisions, observations, or deviations to this TCP made during sample receipt, preparation, and analysis shall be documented and justified in the deliverable report.

\subsection{Preparation of Sample Media Containers}

The laboratories performing the contracted analytical work shall supply prepared and labeled sample containers (SUMMA canisters and/or selective sorbent sampling media) to Field Analytical Services (FAS) at least 48 hours in advance of the scheduled sampling date. Each sample media container shall be certified as clean and prepared according to procedures called out in Table A.1. FAS shall provide sample identification numbers to the laboratories as requested following the quality assurance/quality control format given in Section 3.1.

\subsection{Flammability of Vapor Space Gases}

Prior to this sampling event and performing any intrusive work on a tank, an assessment of the flammability of the tank vapor space gases is required by standard WHC safety practices. The flammability test is identified in the sampling event work package and performed by Industrial Hygiene Field Services personnel using a combustible gas meter (CGM). Under present guidelines no operational or sampling activity is permitted if a single sample of the tank vapor fuel content is greater than $20 \%$ of the lower flammability limit (LFL). If the CGM sample measures a total fuel content between $10 \%$ and $20 \%$ of the LFL, a vapor sampling activity may continue under CGM monitoring to better identify the hazard leve1. Under $10 \%$ of the LFL the tank is not considered a flammability problem and all scheduled work can proceed (Osborne et al. 1994).

\subsection{Sample Collection}

In fiscal year 1995, the tank TX-105 vapor space shall be sampled through a heated probe in an available riser using the vapor sampling system (VSS) in accordance with laboratory operating procedure L0-080-450 "Collection of SUMMA® Canisters \& Sorbent Tube Samples Using the Vapor Sampling System (VSS)". Table A.1 specifies the sample type, the type of collection media to 
be used, and the number of samples requested. Table A.2 provides a sequence of sampling activities and specifies the sample collection time and the flow rate through the sample collection tubes.

A cleanliness check shall be performed in accordance with procedure LO-080-450, Appendix C. Cleantiness of the VSS shall also be addressed by collecting ambient air SUMMA ${ }^{\otimes}$ samples prior to sampling the tanks using the following conditions: 1) with the VSS manifold and transfer lines fully heated; and 2) without the VSS, upwind of TX-105.

The GC/FID shall be used to monitor organic vapors during the sampling event. The GC/FID shall be operated in accordance with L0-080-450, Appendix D and Bellus (1993).

Table A.1. General Sampling Information

\begin{tabular}{|c|c|c|c|c|}
\hline Sample Container & Prepared By & $\begin{array}{l}\text { Preparation } \\
\text { Procedure }\end{array}$ & Sample Type & $\begin{array}{c}\text { Number of } \\
\text { Samples }\end{array}$ \\
\hline SUMMA® & PNL & PNL-TVP-02 & Tank Air & 6 \\
\hline SUMMA® & PNL & PNL-TVP-02 & $\begin{array}{l}\text { Ambient } \\
\text { Air }\end{array}$ & 2 \\
\hline \multirow[t]{3}{*}{ Triple Sorbent Traps } & ORNL & $\begin{array}{c}\text { AC-OP-300-0907 } \\
\text { CASD-AM-300-WPO1 }\end{array}$ & Tank Air & 12 \\
\hline & ORNL & $A C-0 P-300-0907$ & Field Blank & 2 \\
\hline & ORNL & $A C-0 P-300-0907$ & Trip Blank & 2 \\
\hline \multirow{2}{*}{$\begin{array}{l}\text { Sorbent Trap System } \\
\text { for } \mathrm{NH}_{3}, \mathrm{NO}_{2}, \mathrm{NO}, \mathrm{H}_{2} \mathrm{O} \\
\end{array}$} & PNL & PNL-TVP-09 & Tank Air & 6 \\
\hline & PNL & PNL-TVP-09 & Trip Blank & 3 \\
\hline Tritium Trap & WHC & LA-548-111 & Tank Air & 1 \\
\hline HEPA Filters & WHC & $N / A$ & Tank Air & 4 \\
\hline
\end{tabular}

${ }_{2}^{1}$ One sample taken through the VSS, one sample taken upwind of the tank.

2 preparation procedure for samples spiked with surrogate(s).

\subsection{Radiation Screening and Sample Transport}

All vapor samples shall be stored at the 222-S Laboratory Annex while performing a radiological survey of certain items used during sampling. Surveys are conducted to assure compliance with Department of Transportation (DOT) shipping regulations and offsite laboratory acceptance criteria. Items surveyed include four HEPA filters and one tritium trap and shall be analyzed following procedures specified in a Letter of Instruction (Bratzel 1994). These procedures are reproduced in Table A.4.

The results from the radiation screening are submitted to and shall be evaluated by Sampling and Mobile Laboratories to ensure the samples meet the criteria specified in Table A.3. Sampling and Mobile Laboratories shall provide a report to each analytical 1aboratory to identify the number of picocuries per sample ( $\mathrm{pCi} / \mathrm{sample)}$ for each sample that is submitted for analysis. 
Table A.2. List of Samples and Activities.

\begin{tabular}{|c|c|c|c|c|}
\hline $\begin{array}{l}\text { SAMPLE } \\
\text { COOE }\end{array}$ & SAMPLE/ACTIVITY DESCRIPTION & $\begin{array}{l}\text { SAMPLER POSITION } \\
\text { DURING COLLECTIOH }\end{array}$ & GAS FLOW RATE & \begin{tabular}{|c|} 
SAMPLE \\
DURATION \\
\end{tabular} \\
\hline-- & Adjust vSS temperature setpoint to $60^{\circ} \mathrm{C}$ & $N / A$ & $\mathrm{H} / \mathrm{A}$ & H/A \\
\hline-- & Purge vSS with embient air & H/A & $5,450 \mathrm{~mL} / \mathrm{min}$ & $30 \mathrm{~min}$. \\
\hline 01 & Collect ambient air sample SUMMA \#1 & Upwind of $T X-105$ & N/A & $1 \mathrm{~min}$. \\
\hline$\cdots$ & Perform cleanl iness check & $H / A$ & H/A & $\mathrm{H} / \mathrm{A}$ \\
\hline 02 & Collect ambient air sample SUMMA \#2 & Port 15 & N/A & $1 \mathrm{~min}$. \\
\hline$\cdots$ & Leak test & N/A & K/A & N/A \\
\hline$\cdots$ & Purge vSS with tank air & N/A & $5,450 \mathrm{~mL} / \mathrm{min}$ & $30 \mathrm{~min}$. \\
\hline-- & Measure tank pressure & H/A & $\mathrm{H} / \mathrm{A}$ & $N / A$ \\
\hline 03 & Collect Tritium Trap & Sorbent line 8 & $200 \mathrm{~mL} / \mathrm{min}$ & $5 \mathrm{~min}$. \\
\hline$\cdots$ & Collect GC sample and initiate GC run $^{4}$ & $N / \mathbf{A}$ & $\mathrm{H} / \mathrm{A}$ & $N / A$ \\
\hline 04 & Collect SUMMA \#3 OGI & Port 11 & $\mathrm{H} / \mathrm{A}$ & $1 \mathrm{~min}$. \\
\hline 05 & Collect SUMMA \#4 OGI & Port 13 & H/A & 1 min. \\
\hline 06 & Collect SUMMA \#5 OGI & Port 15 & H/A & 1 min. \\
\hline 07 & Collect SUMMA \#6 PHL & Port 12 & N/A & $1 \mathrm{~min}$. \\
\hline 08 & Collect SUMMA $\# 7$ PNL & Port 14 & $\mathrm{H} / \mathrm{A}$ & 1 min. \\
\hline 09 & Collect SUMMA \#8 PHL & Port 16 & $N / A$ & 1 min. \\
\hline 10 & Collect Triple Sorbent Trap (TST) sample \#1 & Sorbent line 9 & $50 \mathrm{~mL} / \mathrm{min}$ & 4 min. \\
\hline 11 & Collect TST sample \#2 & Sorbent line 10 & $50 \mathrm{~mL} / \mathrm{min}$ & 4 min. \\
\hline 12 & Collect TST sample $\# 3$ & Sorbent line 8 & $50 \mathrm{~mL} / \mathrm{min}$ & 4 min. \\
\hline 13 & Open, close, \& store TST Field Blank \#1 & In VSS truck & $0 \mathrm{~mL} / \mathrm{min}$ & N/A \\
\hline 14 & Collect TST sample \#4 & Sorbent line 10 & $50 \mathrm{~mL} / \mathrm{min}$ & $4 \mathrm{~min}$. \\
\hline 15 & Collect TST sample \#5 & Sorbent line 9 & $200 \mathrm{~mL} / \mathrm{min}$ & 5 min. \\
\hline 16 & Collect TST sample \#6 & Sorbent line 10 & $200 \mathrm{~mL} / \mathrm{min}$ & 5 min. \\
\hline 17 & Collect TST sample \#7 & Sorbent line 8 & $200 \mathrm{~mL} / \mathrm{min}$ & $5 \mathrm{~min}$. \\
\hline 18 & Collect TST sample \#8 & Sorbent line 10 & $200 \mathrm{~mL} / \mathrm{min}$ & 5 min. \\
\hline 19 & Collect TST sample \#9 & Sorbent line 9 & $200 \mathrm{~mL} / \mathrm{min}$ & $20 \mathrm{~min}$. \\
\hline 20 & Open, close, \& store TST Field Blank \#2 & In vSS truck & $0 \mathrm{~mL} / \mathrm{min}$ & N/A \\
\hline 21 & Collect TST sample \#10 & Sorbent line 10 & $200 \mathrm{~mL} / \mathrm{min}$ & $20 \mathrm{~min}$. \\
\hline 22 & Collect TST sample \#11 & Sorbent line 8 & $200 \mathrm{~mL} / \mathrm{min}$ & $20 \mathrm{~min}$. \\
\hline 23 & Collect TST sample \#12 & Sorbent line 10 & $200 \mathrm{~mL} / \mathrm{min}$ & 20 min. \\
\hline 24,25 & Store TST Trip Blanks \#1 \& \#2 & Hone & Mone & None \\
\hline 26 & Collect NH3/NOx/H2O Sorbent Trap \#1 & Sorbent line 9 & $200 \mathrm{~mL} / \mathrm{min}$ & 15 min. \\
\hline 27 & Collect $\mathrm{HH} 3 / \mathrm{HOX} / \mathrm{H} 2 \mathrm{O}$ Sorbent Trap $\# 2$ & Sorbent line 10 & $200 \mathrm{~mL} / \mathrm{min}$ & 15 min. \\
\hline 28 & Collect NH3/NOX/H2O Sorbent Trap $\# 3$ & Sorbent line 8 & $200 \mathrm{~mL} / \mathrm{min}$ & 15 min. \\
\hline 29 & Collect NH3/NOx/H2O Sorbent Trap \#4 & Sorbent line 10 & $200 \mathrm{~mL} / \mathrm{min}$ & 15 min. \\
\hline 30 & Collect HH3/HOX/H2O Sorbent Trap \#5 & Sorbent line 9 & $200 \mathrm{~mL} / \mathrm{min}$ & 15 min. \\
\hline 31 & Collect NH3/NOX/H2O Sorbent Trap \#6 & Sorbent line 10 & $200 \mathrm{~mL} / \mathrm{min}$ & 15 min. \\
\hline $32,33,34$ & $\begin{array}{l}\text { Store } \mathrm{NH3} / \mathrm{HOx} / \mathrm{H2O} \text { Trap Trip Blanks \#1, } \\
\# 2, \& \# 3\end{array}$ & None & None & Hone \\
\hline 35 & $\begin{array}{l}\text { Remove upstream HEPA Filter from HEPA } \\
\text { transfer box }\end{array}$ & Upstream of box & \multicolumn{2}{|c|}{ Continuous } \\
\hline 36 & $\begin{array}{l}\text { Remove downstream HEPA Filter from HEPA } \\
\text { transfer box }\end{array}$ & Downstream. of box & \multicolumn{2}{|c|}{ Cont inuous } \\
\hline 37 & Remove upstream HEPA Filter from VSS & Upstream of vss & \multicolumn{2}{|c|}{ Continuous } \\
\hline 38 & Remove downstream HEPA Filter from VSS & Downstream of vSS & \multicolumn{2}{|c|}{ Continuous } \\
\hline
\end{tabular}

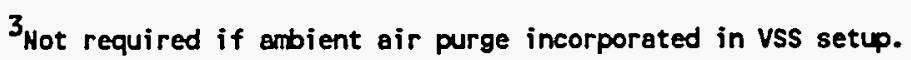

4 Additional GC runs may be performed to obtain organic data and to assure cleanliness of system at the discretion of the sampling scientist and shall be identified in the deliverable report. Organic data obtained from the on-line GC is developmental. 
WHC-SD-HM-TP-293, APPENDIX A, REV 0

Table A.3. Limits For Acceptable Radionuclide Activity Levels.

\begin{tabular}{||c|c|c|c|c|}
\hline \multicolumn{1}{|c|}{ Organization } & Total $\alpha$ & Total B/y & Tritium & Units \\
\hline $\begin{array}{l}\text { PNL Analytical } \\
\text { Chemistry Laboratory }\end{array}$ & $\leq 100$ & $\leq 400$ & -- & $\mathrm{pCi} / \mathrm{g}$ \\
\hline $\begin{array}{l}\text { Oak Ridge National } \\
\text { Laboratory }\end{array}$ & $\leq 135$ & $\leq 450$ & -- & $\mathrm{pCi} / \mathrm{g}$ \\
\hline WHC-CM-2-14 & $\leq 60$ & $\leq 200$ & -- & $\mathrm{pCi} / \mathrm{g}$ \\
\hline
\end{tabular}

${ }^{5}$ Samples sbove these limits may be shipped as Limited Quantity of Radioactive Material.

Trip blanks and field blanks are to accompany the waste samples to the laboratory. For specific information concerning sample and blank handling, custody, and transport refer to quality assurance/quality control requirements in Section 3.1.

\subsection{Tank-Specific Analytical Procedures}

A flowchart and narrative showing the sample collection, isolation, and analysis scheme is presented as Figure A.1. ATI samples are to be prepared and analyzed in accordance with this scheme. Sample receipt, custody, preparation, and analysis shall be performed in accordance with approved procedures.

Sample material retrieved from the tank TX-105 vapor space and contained within the SUMMA® canisters shall be analyzed for total non-methane hydrocarbons following modified EPA procedure T0-14 and the permanent gases $\mathrm{CO}_{2}, \mathrm{CO}, \mathrm{CH}_{4}, \mathrm{H}_{2}$, and $\mathrm{N}_{2} \mathrm{O}$ using gas chromatography. The sorbent traps contain analyte-specific sorbent media and shall be analyzed for these specific analytes. The triple sorbent traps contain sorbent media designed to allow a broad range of organic species to be retained. Table A.4 identifies the appropriate laboratory procedures used in each analysis.

Any analyses prescribed by this document, but not performed, shall be identified and justification for non-performance written in the appropriate data report. If there are insufficient samples to perform all requested analyses, a partial listing of the analyses in Table A.4 that could be performed with available samples will be developed by Tank Vapor Issue Resolution Program personnel. The laboratory shall proceed with these analyses. 
-Step 1 Labs: Prepare sample and blank containers at contract laboratories. Label containers using sample identification numbers and sampling data provided by Field Analytical Services.

-Step 2 Labs: Ship containers to Field Analytical Services at least 48 hours in advance of scheduled sampl ing event. Receipt and control of containers shall be guided by procedures PNL-TVP-07 and CASD-AM-300-WP02 (ORNL).

-Step 3 SHL: If tank is safe with regard to flammability, set up vapor sampling system (VSS) and collect samples following procedure L0-080-450 and guidel ines in Table A.2.

-step 4 SML: Move to the 222-S Laboratory, the vapor sample containers for locked storage, and the HEPA filters and Tritium Trap for radiological survey.

-Step 5 SML: Using radiological survey report results, determine if samples are acceptable to ship offsite (see Section 2.4).

-Step 6 SML: If determined to be acceptable by offsite laboratory requirements and HHC-CM-2-14, ship samples and blanks following DOT requirements. If not acceptable to ship, maintain samples in storage and contact $J$. $W$. Osborne of Vapor Issue Resolution Program for further direction.

-Step 7 Labs: Perform laboratory analyses.

A. SUMMA Canisters (PHL): Perform modified full scan EPA-TO-14. Perform permanent gas analysis for the following: $\mathrm{H}_{2}, \mathrm{CO}, \mathrm{N}_{2} \mathrm{O}, \mathrm{CH}_{4}, \mathrm{CO}_{2}$.

B. Sorbent Traps (PNL): Perform gravimetric analysis for moisture. Perform selective electrode analys is for $\mathrm{NH}_{3}$ Analyze $\mathrm{NO}$ and $\mathrm{NO}_{2}$ Traps.

C. Triple Sorbent Traps (ORNL): Perform organic vapor analysis.

-Step 8 Labs and SHL: Following the Section 6.0 reporting requirements, deliver a format VI Report to the Vapor Issue Resolution Sefety Program.

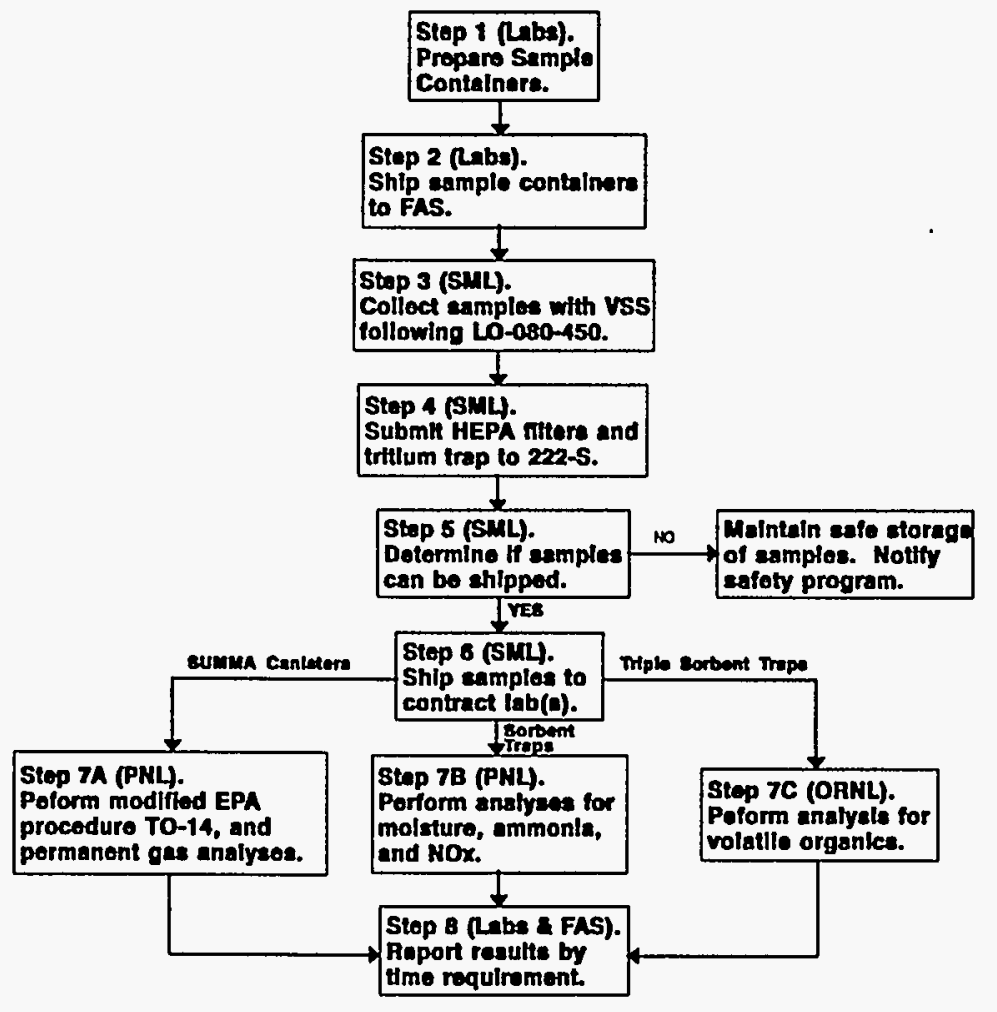


WHC-SD-WM-TP-293, APPENDIX A, REV 0

Table A.4. TX-105 Sample Chemical, Physical, and Radiological Analytical Requirements

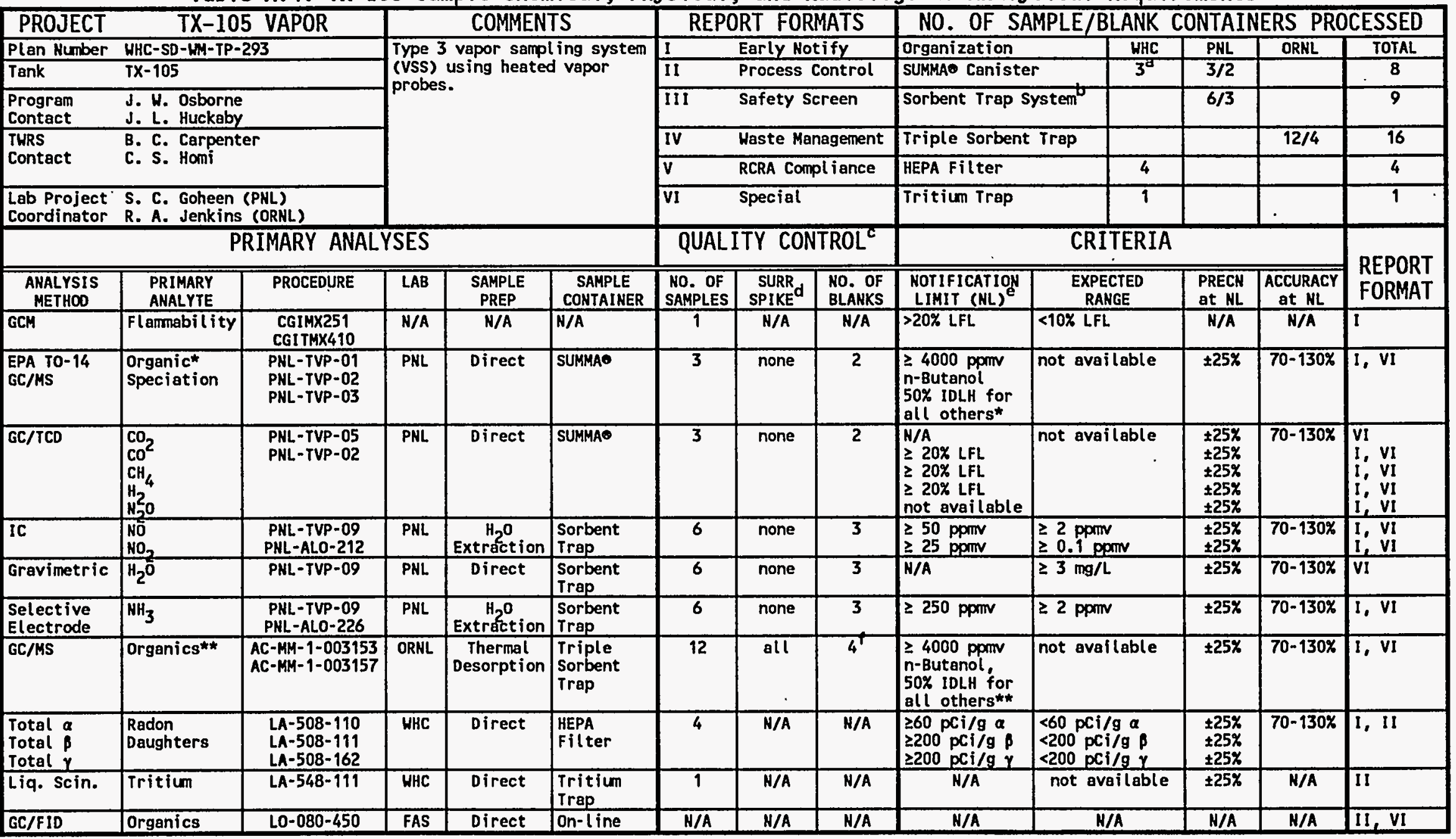

H/A: Not Applicable

a Three canisters will be archived at PNL until arrangements cen be made for transport and analytical work at the OGIST laboratory.

b System contains individual sorbent media sections for $\mathrm{NO}_{\mathrm{X}}, \mathrm{NH}_{3}, \& \mathrm{H}_{2} \mathrm{O}$.

c Multiple samples and blanks are taken.

d Samples spiked with surrogates.

e Action required if any compound exceed $50 \%$ IOLH.

includes two trip and two field blanks.
*Acetone, acetonitrile, benzene, 1,3-butadiene, butanal, n-butanol, n-hexane, methane, propane nitrile. Other organic species detected at levels deemed sufficient by the laboratory scientist to be of potential toxicological concern shall be reported following format I.

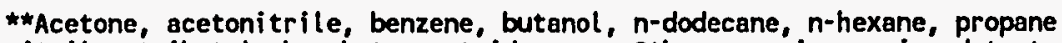
nitrile, tributyl phosphate, n-tridecane. Other organic species detected at level deemed sufficient by the laboratory scientist to be of potential toxicological concern shall be reported fol lowing format I. 


\subsection{QUALITY ASSURANCE/QUALITY CONTROL}

This Tank Characterization Plan and analytical laboratory operations are approved by the WHC Environmental Safety, Health, and Quality Assurance (ESH\&QA) Program provided the following conditions are met.

1) Each 1aboratory has a quality assurance program that meets the applicable requirements of DOE order 5700.6C, American Society of Mechanical Engineers NQA-1, EPA QAMS-005/80 or United States 10 CFR 830.120 .

2) Each analysis and media preparation procedure given in Tables A.1 and A. 4 is documented by the laboratory and available to ESH\&QA.

3) Any modifications made to, or deviations from, the prescribed procedures are documented and justified in the deliverabie report.

The PNL tank vapor program has an impact level II Laboratory Quality Assurance Plan (Barnes 1994) written to comply with 5700.6C. ESH\&QA will qualify laboratories for continued use by the TWRS Characterization program after receipt of the Laboratory quality assurance plans, followed by an audit and corrective action phase.

\subsection{Sampling Operations}

The laboratory supplying the sample collection media shall initiate the chain-of-custody form in accordance with the laboratory operating procedure L0-090-443 "Chain-of-Custody for RCRA and CERCLA Protocol Samples" using unique sample Tabel and identification numbers provided by FAS. Each sample identification number shall have the following format:

SXXXX-WYY-LLL, where:

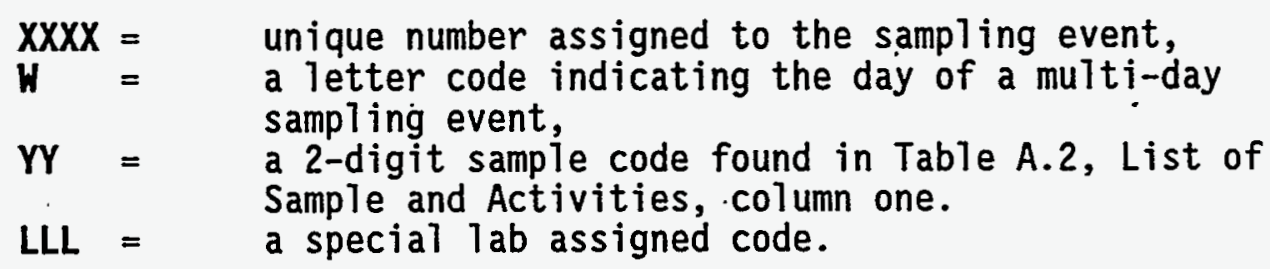

Once the sample collection media has been received by FAS from the laboratory, it shall remain in the physical control of the custodian, locked in a secure area, or prepared for shipping with tamper evident tape. The sample collection media shall also remain in a controlled area under conditions specified on the chain-of-custody form.

Applicable operating procedures for the tank TX-105 vapor space sampling activities are contained in work package WS-94-862. Vapor samples, trip blanks, and field blanks are to be collected in accordance with Tables A.1 and A. 2 and laboratory operating procedure LO-080-450 "Collection of SUMMA® Canisters \& Sorbent Tube Samples Using the Vapor Sampling System (VSS)" and shipped to the analytical 1aboratories in accordance with Hazardous Material Packaging and Shipping, WHC-CM-2-14. 
All sampling activities shall be documented in controlled field logbooks maintained by sampling personnel (Sampling and Mobile Laboratories) and shall contain, but are not limited to:

1) identification of tank and riser number and photographs of the sample location in which the sampling is conducted,

2) if any anomalies are observed, corresponding sample identification numbers, flow rates, pressures, temperatures, and other operational parameters affecting the sample,

3) any conditions that the sampler may observe during the sampling event ( $i$. e., odors, nearby machinery in operation, etc.),

4) names and titles of personnel involved in the field activity and their responsibilities,

5) instrument calibration dates.

Sampling and Mobile Laboratories is responsible for documenting any problems and procedural changes affecting the validity of the sample in a controlled field notebook and shall enter this information in the comment section of the chain-of-custody form for addition to the data reports.

\subsection{Laboratory Operations}

Prepared and labeled sample collection containers, trip blanks, and field blanks are supplied by the performing laboratories to FAS. The SUMMA ${ }^{\circledR}$ canisters and Sorbent Trap Systems are prepared and certified following the laboratory quality control procedures identified in Table A.1. The laboratory supplying the sample collection media shall initiate the chain of custody in accordance with the Taboratory operating procedure L0-090-443, "Chain-ofCustody for RCRA and CERCLA Protocol Samples" using sample label and identification numbers provided by Field Analytical Services.

The sample receipt and control steps used in the PNL laboratories are identified in procedure PNL-TVP-07. Oak Ridge National Laboratory shipping and receiving is done by procedure CASD-AM-300-HP02. Analyses will be performed according to the procedures in Table A.4.

Method specific quality control such as calibrations and blanks are also found in the analytical procedures. Sample quality control (duplicates, spikes, standards) are identified in Table A.4. If no criteria are provided in Table A.4, the performing laboratory shall analyze quality control samples according to its Quality Assurance Plan(s).

Due to the developmental work being done with the analysis procedures and potential sample differences (between tanks), changes in procedures may be needed. These changes must be documented in controlled notebooks and referenced in the deliverable reports to ensure traceability. 


\subsection{ORGANIZATION}

The organization and responsibility of key personnel involved in this tank TX-105 vapor sampling project are listed in Table A.5.

Table A.5. Tank TX-105 Project Key Personnel List.

\begin{tabular}{|c|c|c|}
\hline Individual(s) & Organization & Responsibility \\
\hline S. C. Goheen & $\begin{array}{l}\text { Pacific Northwest } \\
\text { Laboratory }\end{array}$ & $\begin{array}{l}\text { Project Manager for Vapor } \\
\text { Sample Characterization }\end{array}$ \\
\hline R. A. Jenkins & $\begin{array}{l}\text { Oak Ridge National } \\
\text { Laboratory }\end{array}$ & $\begin{array}{l}\text { Project Manager for Vapor } \\
\text { Sample Characterization }\end{array}$ \\
\hline J. G. Kristofzski & WHC 222-S Laboratory & $\begin{array}{l}\text { Project Manager for Sample } \\
\text { Radiological Survey }\end{array}$ \\
\hline $\begin{array}{l}\text { B. C. Carpenter } \\
\text { C. S. Homi }\end{array}$ & $\begin{array}{c}\text { TWRS Characterization } \\
\text { Support }\end{array}$ & $\begin{array}{l}\text { TX-105 Tank Characterization } \\
\text { Plan Engineers } \\
\end{array}$ \\
\hline J. H. Osborne & $\begin{array}{l}\text { TWRS Tank Vapor Issue } \\
\text { Resolution Program }\end{array}$ & $\begin{array}{l}\text { Vapor Issue Resolution } \\
\text { Program Manager }\end{array}$ \\
\hline H. Babad & $\begin{array}{c}\text { TWRS Characterization } \\
\text { Program }\end{array}$ & $\begin{array}{c}\text { Tank Safety Screening } \\
\text { Scientist }\end{array}$ \\
\hline R. S. Viswanath & $\begin{array}{l}\text { Field Analytical } \\
\text { Services }\end{array}$ & $\begin{array}{c}\text { Special Analytical Studies } \\
\text { Vapor Sampling Technical } \\
\text { Support }\end{array}$ \\
\hline R. D. Mahon & $\begin{array}{l}\text { Field Analytical } \\
\text { Services }\end{array}$ & $\begin{array}{c}\text { Sampling and Mobile } \\
\text { Laboratories Vapor Sampling } \\
\text { Program Lead }\end{array}$ \\
\hline E. H. Neilsen & $\begin{array}{c}\text { Waste Tank Safety } \\
\text { Engineering }\end{array}$ & $\begin{array}{l}\text { Vapor Sampling } \\
\text { Cognizant Engineer }\end{array}$ \\
\hline D. R. Carls & $\begin{array}{l}\text { Industrial Hygiene } \\
\text { and Safety Program }\end{array}$ & $\begin{array}{l}\text { Industrial Hygiene Point of } \\
\text { Contact if Notification Limit } \\
\text { is Exceeded (FAX 372-3522) }\end{array}$ \\
\hline $\begin{array}{c}\text { East Area Shift } \\
\text { Operations } \\
\text { Manager }\end{array}$ & Tank Farm Operations & $\begin{array}{l}\text { East Tank Farm Point of } \\
\text { Contact if Notification Limit } \\
\text { is Exceeded (373-2689) }\end{array}$ \\
\hline
\end{tabular}

\subsection{EXCEPTIONS, CLARIFICATIONS, AND -ASSUMPTIONS}

Trip Blanks and Field Blanks

Trip Blanks are sampling devices prepared and handled in the same manner as samples, except that they are never opened in the field. Field Blanks are sampling devices prepared and handled in the same manner as the samples, but no tank gases are drawn through them. Laboratories supplying blanks may opt to analyze only 1 trip blank unless it is determined to be contaminated, in which case all trip blanks are to be analyzed. 
WHC-SD-WH-TP-293, APPENDIX A, REV 0

Sample Custodian

The sample custodian is the designated FAS cognizant scientist or assisting scientific technician, lead sampler, or laboratory scientist or technician who signs the received by block on the chain-of-custody. Transfer of custodianship occurs when the custodian signs the relinquished by block on the chain-of-custody and releases the sample(s) to the new custodian signator.

\section{Physical Control}

Physical control of a sample includes being in the sight of the custodian, in a room which shall signal an alarm when entered, or locked in a cabinet.

\subsection{DELIVERABLES}

The Pacific Northwest Laboratory, Oak Ridge National Laboratory, and Sampling and Mobile Laboratories VSS sampling and analyses of tank TX-105 vapors shal7 be reported as Format VI (Section 6.3). In addition, the analytical 1aboratories shall receive Format II reports from Sampling and Mobile Laboratories as described in Section 6.2. Any analyte exceeding the notification limit prescribed in Table A.4 shall be reported as Format I (Section 6.1). Other organic species detected at levels deemed sufficient by the laboratory scientist to be of potential toxicological concern shall also be reported following Format $I$. Additional information regarding reporting formats is given in Schreiber (1994a, 1994b, 1994c).

\subsection{Format I Reporting}

Table A.4 contains the notification limits for specific analytes. Analytes that exceed notification limits defined in the DQO processes shall be reported by the Project Manager, delegate, or Health Physics Management by calling the East Area Shift Manager of Tank Farm Operations at (509) 373-2689 immediately. This verbal communication must be followed within 3 working days by written communication to J. H. Osborne of the Tank Vapor Issue Resolution Program, D. R. Carls in the Industrial Hygiene and Safety Program, and D. R. Bratze] of the Characterization Program, documenting the observation(s). A further review of the data, including quality control results and additional analyses for verification of the exceeded analyte, may be contracted between the performing laboratory and the contacts above.

\subsection{Format II Reporting}

Results of the 222-S Laboratory's radiological survey shall be reported by Sampling and Mobile Laboratories as Format II to the vapor analytical laboratories listing the picocuries per sample ( $\mathrm{pCi} / \mathrm{g} / \mathrm{sample}$ ) for each sample submitted for analysis. This Format II report should also provide the sample collection sequence and volumes, verification of trip and field blank use, and any anomalous sampling conditions to accompany, if possible, the shipment of samples. Alternatively, this sampling report may be transmitted by FAX to the analytical laboratories within 48 hours after the samples have been shipped.

\subsection{Format VI Reporting}

All Format VI reports shall be delivered to J. W. Osborne of the Tank Vapor Safety Resolution Program, R. S. Viswaneth of Field Analytical Services, 
the Characterization Program Office, Analytical Services, and the Tank Characterization Resource Center.

Each analytical laboratory and SML shall deliver three reports. Sampling and analytical data are requested within 5 weeks after receipt of both the samples and supporting data and shall consist of, at a minimum, data tables reporting sample collection data, industrial hygiene tank monitoring data, and radiation screening results obtained by SML, or the results of each analysis performed by the analytical laboratories. A final report shall be delivered within a nine week period after receipt of both the samples and supporting data. A cleared final report shall be delivered after it has completed the proper clearance. Final reports shall be submitted to clearance in parallel to being submitted to the WHC customers identified above.

The final sampling report from Sampling and Mobile Laboratories shall be a WHC supporting document, with sponsor-limited release. It should include:

1) A description of sampling equipment used;

2) a description of sampling quality controls applied (e.g., leak and cleanliness tests of the sampling manifold, system temperature and pressure monitoring/alarms, instrument calibration details);

3) sampling event chronology and sample collection schedule (complete list of samples, by ID\#, time collected, flow rates, etc.);

4) any industrial hygiene tank monitoring data collected before or during sampling event;

5) an evaluation of sources of sampling errors;

6) sample radiation screening results;

7) sample storage and shipment details; and

8) copies of all chain-of-custody forms.

The cleared final report from the analytical laboratories shall be acceptable for distribution to the public. To the extent possible, the final reports should include:

1) A summary of analytical results;

2) a description of sample device preparation (and manufacture if appropriate), citing procedures and logbooks used;

3) references providing traceability of sample device cleanliness;

4) a brief description of analytical methods, with procedures cited;

5) a brief explanation of how analytical systems control was demonstratably maintained;

6) a brief description of sample storage and shipment conditions, citing procedures and logbooks used;

7) a listing of analytes of quantitation (target analytes), with analytical method detection limit, range for which instrumentation is calibrated, number of calibration points used, and statistical data on linearity of calibration;

8) quantitative analytical results, expressed as dimensionless (ppmv or ppbv) concentration, and mass concentration $\left(\mu \mathrm{g} / \mathrm{m}^{3}, \mathrm{mg} / \mathrm{L}\right.$, etc., calculated at $0{ }^{\circ} \mathrm{C}$ and $1 \mathrm{~atm}$ ) of target analytes (identified by name and Chemical Abstract Service number) in each tank air sample;

9) tentative identification and semi-quantitative analytical results, expressed in both mass and dimensionless concentrations (if possible) of non-target organic analytes (identified by name and Chemical Abstract Service number) in each organic vapor sample; 
10) a statistical summary (i.e., mean, standard deviation) for multiple analyses and/or multiple samples for all analytes (positively and tentatively identified compounds) in both mass and dimensionless concentrations (if possible);

11) a summary of al1 exceptional conditions, such as deviations from procedure or protocol, results obtained outside of instrument calibration range, sorbent trap breakthrough of analytes, or poor surrogate recoveries; and

12) copies of chain-of-custody forms attached.

\subsection{CHANGE CONTROL}

Under certain circumstances, it may become necessary for the performing laboratory to make decisions concerning a sample without review of the data by the customer or the Characterization Program. These changes shall be brought to the attention of the project manager and the Characterization Program as quickly as possible and documented accordingly. Changes must be justified in their documentation. Changes may be documented through the use of internal change notices or analytical deviation reports for minor, low-impact changes. A11 significant changes (such as changes in scope) shall be documented by Characterization Support via an Engineering Change Notice to this Tank Characterization Plan. All changes shall also be clearly documented in the final data package.

Additional analysis of sample material from this vapor space characterization project at the request of the Characterization Program shall be performed according to a revision of this Tank Characterization Plan.

\subsection{REFERENCES}

American Society of Mechanical Engineers, NQA-1, Quality Assurance Program Requirements for Nuclear Facilities.

Barnes, B. 0., 1994, Quality Assurance Plan for TWRS Waste Tank Safety Program, MCS-027 Rev. 4, Pacific Northwest Laboratory, Richland, Washington.

Bratzel, D. R., 1994, Letter or Instruction for Radiological Analyses to Support Fiscal Year 1995 Tank Vapor Sampling, (internal memo 74310-94-32 to J. G. Kristofzski, November 30), Westinghouse Hanford Company, Richland, Washington.

Bellus, T. H., 1993, Configuration of Hewlett Packard (HP) 5890 Series II Gas Chromatograph (GC) for DHL1, (internal memo 12240-SAA93-039 to L. L. Lockrem, JuTy 10), Westinghouse Hanford Company, Richland, Washington.

Environmental Protection Agency, QAMS-005/80, Interim Guidelines and Specifications for Preparing QA Project Plans.

Keller, K. K., 1994, Quality Assurance Project Plan for Tank Vapor Characterization, HHC-SD-WM-QAPP-013, Rev.2, Westinghouse Hanford Company, Richland, Washington. 
Meznarich, H. K., 1994, Quality Assurance Program Plan for Laboratory Analysis and Process Testing, WHC-SD-CP-QAPP-003, Rev. 1, Westinghouse Hanford Company, Richland, Washington.

Osborne, J. H., J. L. Huckaby, E. R. Hewitt, C. M. Anderson, D. D. Mahlum, B. A. Pulsipher, J. Y. Young, 1994, Data Quality Objectives for Generic InTank Health and Safety Vapor Issue Resolution, WHC-SD-WM-DQO-002, Rev. 0 , Westinghouse Hanford Company, Richland, Washington.

Schreiber, R. D., 1994a, Format I Reporting Requirement, (internal memo 7E720-94-128 to J. G. Kristofzski, August 15), Westinghouse Hanford Company, Richland, Washington.

Schreiber, R. D., 1994b, Revised Interim Tank Characterization Plan Guidance, (7etter 7E720-94-121 to C. S. Haller, May 13), Westinghouse Hanford Company, Richland, Washington.

Schreiber, R. D., 1994c, Point of Contact/Distribution List, (internal memo 7E720-94-141 to J. G. Kristofzski, October 11), Westinghouse Hanford Company, Richland, Washington.

United States Department of Energy Order 5700.6C, of 08-21-91, Quality Assurance.

United States Code of Federal Regulations, 10 CFR Part 830, Nuclear Safety Management; Section 120, Quality Assurance Requirements.

Whelan, T. E., 1994, TWRS Characterization Program Quality Assurance Program Plan, WHC-SD-WM-QAPP-025, Westinghouse Hanford Company, Rich7and, WA. 